\title{
A nyújtási technikák elemzése a rekreációs sporttevékenységek szempontjából
}

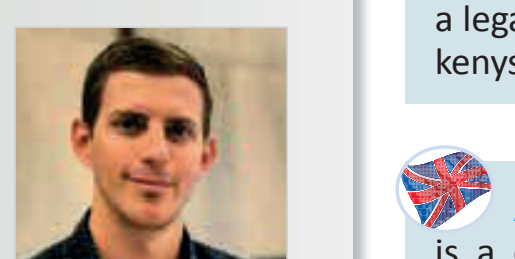

ABSTRACT: Stretching techniques is a constantly researched area of sport sciences, the current leading trends of techniques in professional sports are changing from time to time. These trends are highly prefered methods in the field of recreational sports activities. In order to keep health promotion in mind we have to examine, which stretching techniques are the most capable for the purpose of recreational sports activities, since the goal settings are different in case of professional

\section{Bevezetés}

A rekreációs sporttevékenyégek térhódítása napjainkban növekvő tendenciát mutatnak. Egyre több tudományos kutatás világít rá a fizikai aktivitás fontosságára, az egészség megőrzésében betöltött pozitív szerepére (Apor et al., 2007; Bailey D.A. et al., 2013; Cabane C. et al., 2014; Ihász et al., 2015; Pavlik, 2015). Ezek az eredmények nagy számban jutnak el átlagemberekhez is. Ezáltal az élsportban alkalmazott technikák és eszközök is bekerülhetnek a rekreációs sportot üzők rendszerébe, de korántsem biztos, hogy ezek közül mind pozitív hatással bír a rekreációs céllal sportolókra.

A versenysport alapvető célja a minél jobb teljesítmény elérése, a mások eredményeinek túlszárnyalása, egységesített szabályok és a pontos mérési módszerek alkalmazásával (Balogh, 2015). „A mozgásos rekreáció célja az egészség megőrzése, fejlesztése, a testi-lelki jólét megteremtése, s hogy az alkalmazott módszereket e cél elérése érdekében használjuk. A mozgásos rekreáció tehát olyan gyakorlatok végrehajtá- az egészség megőrzését tartsuk szem előtt. A két fő nyújtási technika (statikus-dinamikus nyújtás), az edzés két különböző részében alkalmazható (bemelegítés, levezetés), és néhány esetben ezek felhasználása ellentétesek az élsportban és a rekreációban. A jövőben érdemes az elérni kívánt cél szerint választani a nyújtási technikák közül, és ennek megfelelően differenciálni a széles körű tudományos eredmények között.

Kulcsszavak:

rekreációs edzés, nyújtás, prevenció sports and recreational sports.

We can use two main stretching technic (static and dynamic) in different parts during the training (warm up cool down). In some cases the application of the methods is opposite in professional sport and recreation. We suggest to choose the right stretching method according to our goal and differentiate among the widespread scientific results.

Keywords:

recreation, stretching, prevention

sából álló tevékenység, melynek célja az egyén egészségének megőrzése és fejlesztése, teljesítô- és munkavégző képességének helyreállítása és szükség szerint annak növelése." (Fritz, 2018. p. 25.) A teljesítményközpontú gondolkodást az egészségközpontú gondolkodásmód váltja fel a mozgásos rekreáció esetében. Itt a teljesítmény az egyéni fittség és edzettség megőrzésének eszközévé válik (Fritz, 2018).

Az eltérő célrendszerből adódik a különböző edzéseszközök és -módszerek alkalmazása. Az edzés eszköztárán belül írásunkban a nyújtási technikákra fókuszálunk. Érdemes megvizsgálni, hogy az egyes nyújtási típusoknak milyen előnyei és hátrányai vannak, és ezek hogyan illeszthetők a rekreációs sporttevékenységek mozgásanyagába.

A hajlékonyság minden életkorban edzhető képesség, az ízületek mozgástartománya az életkor előrehaladtával fokozatosan szúkül, amely az idősebb korosztály kevesebb fizikai aktivitásával is összefüggésben van (Vannai, 2019). 


\section{Nyújtási technikák bemutatása}

A témában történő kutatások segítségével egyreátfogóbb, pontosabb képet kapunk az egyes nyújtástípusok biomechanikai és élettani hatásáról. Általánosságban elmondható, hogy a nagyobb mozgásterjedelem pozitívan befolyásolja a sportteljesítményt, ezért a hajlékonyságot fejlesztő gyakorlatok edzéseken vagy versenyeken gyakran szerepelnek a bemelegítő részben (Radák, 2016). Nyújtás alkalmával az izomrostok széthúzódnak, és a szarkomérák ( $a$ harántcsíkolt izmok funkcionális egységei) olyan állapotba kerülnek, hogy nem lesz átfedés az aktin és miozin fehérjeszálak (az izomsejtek kontraktilis fehérjéi) között, ekkor a környező kötőszöveteknek kell átvenni a tartás szerepét. Fontos kiemelni, hogy a nyújtás elhanyagolása ízületi mozgáspályák beszúkülését, ízületi kontraktúrát, sérüléseket eredményezhet (Tánczos, 2018). Az elkövetkezendőkben négy, a mozgás dinamikájának szempontjából különböző nyújtástípust járunk körül, és mutatunk be. A leggyakrabban alkalmazott nyújtási típusok: statikus nyújtás (stretching), dinamikus nyújtás, Proprioceptív Neuromuszkuláris Facilitáció (PNF) nyújtás, ballisztikus nyújtás.

\section{Statikus nyújtás (stretching):}

Az izom megnyújtásának egyik legbiztonságosabb és leggyakrabban használt módszere a stretching, melynek hatása egészen más lehet a különböző terhelések előtt vagy után. Szubmaximális aerob terhelés után a stretching kedvező hatásait írták le a mozgásterjedelemre és a sérülékenység csökkentésére, míg közvetlenül a verseny előtti stretchinggel óvatosabban kell bánni, mert sérülést is okozhat. Fontos kiemelni, hogy az izom nyújtása során 6-15 másodperc szükséges az izom teljes relaxációjához, így 20 másodpercnél hosszabb nyújtásra nincs szükség, mivel a gyors nyújtás növeli az izomfeszülést, ezért ezt a típusú nyújtást lassan, utánmozgás nélkül kell végezni a nagyobb mozgáskiterjedés eléréséhez (Radák, 2016). Napjainkban számos kutatás foglalkozik a statikus nyújtás és a teljesítmény kapcsolatával, ilyen például Saolidis és munkatársainak kutatása (2010), akik megállapították, hogy negatív hatással van a verseny elótti statikus nyújtás a 20 méteres sprintfutás eredményére. Korábbi kutatásokban is (1980-as évek) kimutatták, hogy az edzés előtt végzett statikus nyújtás csökkentheti a teljesítmény leadását, ezért aztán a statikus nyújtás fokozatosan kezdett eltűnni az élsportból, és megjelent a dinamikus nyújtás. Valóban az izom teljesítményének rövid távú csökkenéséhez vezethet a statikus nyújtás. Az érem másik oldala, hogy a hajlékonyság hiánya miatt fokozatosan kialakuló, idősödő felnőtteket és sportolókat különösen sújtó, sérülések (háti gerinc alsó szakaszának sérülései, krónikus térd- és vállízület fájdalma) hátterében szerepet játszanak a dinamikus nyújtásra nem reagáló hosszú távú szöveti változások (Boyle, 2014). Ez fakadhat abból, hogy a 15-30 másodpercig tartó passzív statikus nyújtás hatékonyabban javítja a mozgástartományt, mint a dinamikus nyújtás (D’Anna - Gomez, 2015). 1. ábra

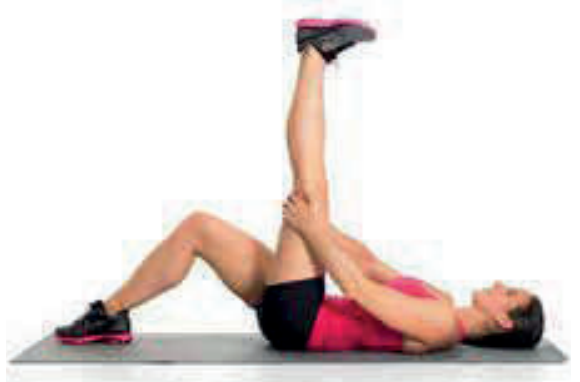

1. ábra:

A combhajlító izom statikus nyújtása Static stretching of the Hamstring Kép forrása: www.runnersworld.com/races-places

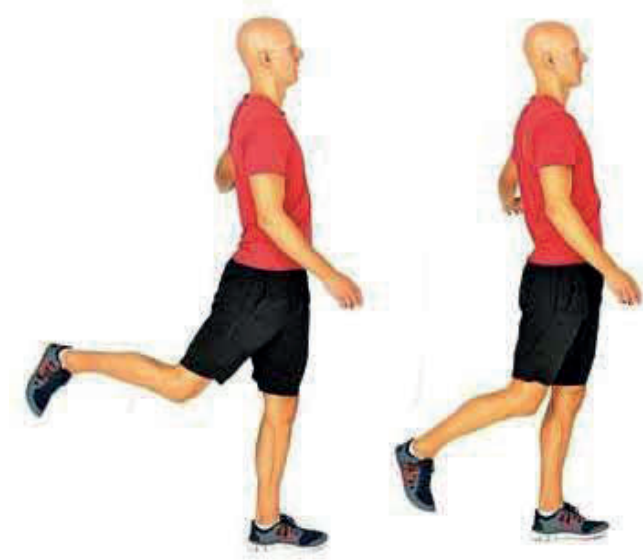

2. ábra: A combhajlító izom dinamikus nyújtása / Dynamic stretching of the Hamstring

Kép forrása: www.yurielkaim.com/dynamic-warm-up-exercises

\section{Dinamikus nyújtás:}

Akkor beszélünk erról a nyújtásfajtáról, amikor az ízületi mozgáshatárt lassú, közepes vagy gyors mozgással érjük el, az érintett izomcsoportot csak egy pillanatra nyújtjuk meg. Fontos kiemelni, hogy a mozgáshatárig történik a nyújtás, azon nem halad át, tehát az ízületi mozgáshatárnál meg kell állítani a mozdulatot. A gyakorlatok állhatnak kontrollált húzásokból, lendítésekből, fordításokból (Tánczos, 2018). Több kutatás alátámasztja (Fletcher - Jones, 2005; Little - Williams 2006; Zmijewski et al., 2020), hogy a dinamikus nyújtás nagy előnye, hogy segíti az izmok hőtermelését, és rövid távon nem rontja az izmok teljesítményét, sőt egyes esetekben javítja azt. Ezzel szemben Metzing (2010) rávilágít, hogy a dinamikus nyújtások első nyújtásingerként történő alkalmazása még a bemelegített izomra nézve is sérülésveszélyt jelenthet. Kutatások hívták fel rá a figyelmet, hogy a lendülettel, gyors mozgással elért mozgáshatárokon az izomban a gyors megnyúlásra beindul az izom védekező reflexe. A proprioreceptorok (izomorsó és Golgi-készülék) a hirtelen fellépő hosszváltozást az izomra nézve veszélyként érzékelik, beindul a myotatikus reflex, melynek hatására az izom hirtelen gyors összehúzódásra kap parancsot. Az akaratlagos, gyors izomnyújtási szándék, konfliktusba kerül a védekező mechanizmussal. Ez a két ellentétes irányú folyamat okozhatja az izom mikrosérüléseit, súlyosabb esetben az izom szakadását, és akár kisebb izomrostsérüléseket az edzést követő napon „izomlázként" izomfájdalmak formájában

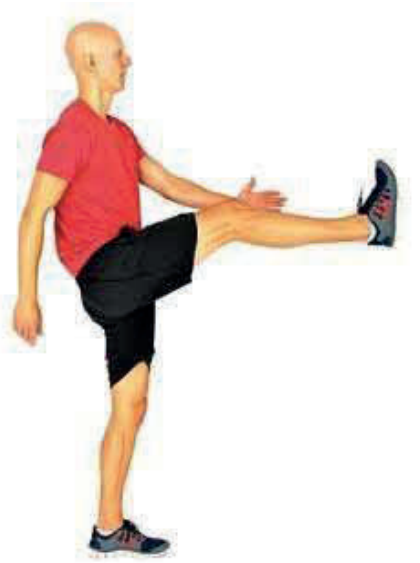


is érzékeljük. A sérülésveszély mellett meg kell említeni, hogy a dinamikus nyújtás nem olyan hatékony az izomrugalmasság hosszú távú növelésének szempontjából (Zmijewski et al., 2020). 2. ábra

\section{Ballisztikus nyújtás:}

E nyújtástípus sajátossága, hogy van egy olyan pillanat amikor a mozgás az egész testet vagy a végtagot a normál mozgásterjedelemnél nagyobb kilendülésre kényszeríti. Lényegében úgy is jellemezhetjük, hogy a megfeszített testtartásból „kiugrunk” majd vissza, a megfeszített izmot úgy használva, mint egy rugót, pl. amikor lendületból megérintgetjük kezünkkel a lábujjunkat (Müller - Rácz, 2011). Ezek a gyakorlatok kevésbé alkalmasak az ízületi mozgástartomány növeléséhez (Váczi, 2015). A mozdulatok általában után mozgásokkal történnek, ennek következtében a túlnyújtás következhet be. A hirtelen mozdulat nem engedi az izmot alkalmazkodni, pihentetni a nyújtott állapotban, helyette ismétlődően felléphet a nyújtási reflex. D’Anna és Gomez (2015) szerint a ballisztikus nyújtás során az izmokban mikrorepedések keletkeznek, amelyek a kötőszövet szintjére is átterjedhetnek, és ezek a nyújtási manőverek az izmok, inak, szalagok sérüléseit okozhatják ( $R a-$ dák, 2016). 3. ábra

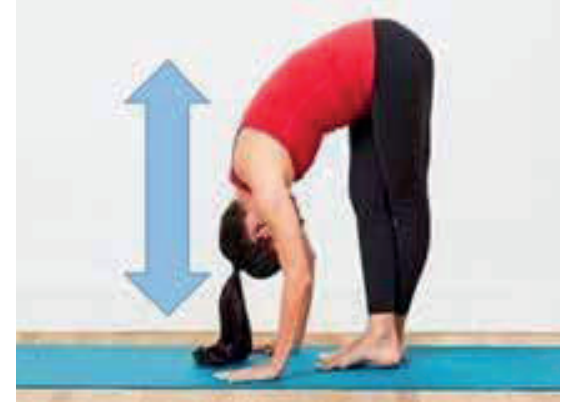

3. ábra:

A combhajlító izom ballisztikus nyújtása

Ballistic stretching of the Hamstring

Kép forrása: https://hu.pinterest.com/pin

\section{Proprioceptív}

Neuromuszkuláris Facilitáció (PNF) nyújtás

A PNF nyújtás olyan módszer, amely a dinamikus nyújtással ellentétben kikapcsolja a nyújtási reflexet, egy relaxált izomállapotot hoz- va létre, mely során jól nyújtható az izom- és ínrendszer. E módszernél növekszik a nyújthatóság és csökken a sérülésveszély. Többféle PNF nyújtástípus ismert, melyek közös pontja a proprioreceptorok neuromusculáris stimulációja, vagyis hogy „megpróbáljuk becsapni” az izomorsót és a Golgi-készüléket, annak érdekében, hogy ne jöjjön létre a nyújtási reflex. Az egyik legismertebb módszer a kontrakció-relaxáció módszere, mely során az izmot az ízületi mozgáshatárig nyújtjuk, majd statikus ellenállással szemben rövidülnek az izom kontraktilis elemei úgy, hogy az izom hossza nem változik (izometrikus erókifejtés), ennek az erőkifejtésnek legalább 6 másodpercig kell tartania, mely után az izom relaxálódik és jó hatékonysággal lesz nyújtható, ahol a passzív nyújtásnak 20 másodpercig kell tartania, ezt érdemes 3-4 szer megismételni (Müller - Rácz, 2011; Radák, 2016). Előnye ennek a nyújtási típusnak a nagymértékü, és hosszú távú izomhossz-növekedés, melyet alacsony sérülésveszély mellett lehet elérni. Hátránya, hogy meglehetősen időigényes, jelentős testtudatot (kinesztézist) igényel, és a nyújtást követően a dinamikus gyors mozdulatok kivitelezése sérüléshez vezethet.

Egy másik szemlélet, mely az emberi test izmait tónusos és fázisos csoportra osztja, Janda, Lewit és Sache (1986) nevéhez füződik. Az általuk megfogalmazott rendszerben a tónusos izmok fó funkciója a stabilizálás, ezen izmok túlfeszülésre és zsugorodásra hajlamosak, ezért sok nyújtást és lazítást igényelnek, lassan aktivizálódnak, de tartós munkára képesek. Ezzel szemben a másik csoport, a fázisos izmok csoportjának a fó funkciója a mobilizálás, ezen izmok gyengülésre, megnyúlásra hajlamosak, ezért elsősorban erősítést igényelnek, gyorsan aktivizálódnak és gyorsan fáradnak. Janda és munkatársainak szemlélete alapján tisztán látszik, hogy mely izomcsoportok azok, melyeket nyújtani érdemes, ezek közül a legfontosabbak: kétfejú lábikraizom, gázlóizom ( $m$. gastrocnemius, $m$. soleus), egyenes combizom ( $m$. rectus femoris), csípőhorpasz izom (m. iliopsoas), szabóizom (m. sartorius), a comb hajlítóizmai (hamstring), mély hátizmok ( $m$. erector spinae), nagy mellizom ( $m$. pectoralis major), lapockaemelő izom (m. levator scapulae), csuklyásizom felső része (m. trapezius pars superior) (Somhegyi, 2003).

\section{Konklúzió}

A nyújtási technikák jellemzéséből választ kaphatunk a „hogyan” kérdésre, vagyis hogyan érdemes nyújtani, és következtetni tudunk a „mikorra” is, hogy az edzés mely szakaszában mely technikát használjuk. A korábban bemutatott nyújtási metódusok közül a rekreációs célú fizikai aktivitás során a ballisztikus nyújtást nem érdemes használni, hiszen leginkább negatív hatásáról számoltak be a kutatók. A statikus nyújtást tanácsos leginkább alkalmazni már a bemelegítés szakaszában, rövid aerob tevékenységet követően, hiszen megfelelően nyújtja az adott izmot, előkészíti a nagyobb munkavégzésre, és segít a sérülés megelőzésében. A kutatók által bizonyított káros hatása, miszerint rontja a teljesítményt, elhanyagolható a rekreációs edzésben. Ciklikus mozgásformáknál (futás, kerékpár, úszás, nordic walking) és erősítő edzés esetében elegendő a statikus nyújtás bemelegítés gyanánt. Egyéb mozgásformák (sportjátékok, fallabda stb.) esetében érdemes egy rövid dinamikus nyújtó hatású blokkot beiktatni a statikus nyújtás után, hiszen ez által még jobban előkészíthetők a dinamikus gyors, előre nem látható mozdulatok, és jelentősen csökkentjük a sérülésveszélyt (Boyle, 2016). Mivel a dinamikus nyújtás előtt már történik egy statikus nyújtás, így nagymértékben kiküszöbölhetjük a dinamikus nyújtás veszélyeit. A PNF típusú nyújtást, véleményünk szerint legalkalmasabb külön edzésben alkalmazni, így az egyes ízületi kontraktúrák oldására kiváló módszer. A statikus és PNF nyújtási technikák segítenek a helyes testtartás, az ízületek megfelelő mozgáspályáinak megőrzésében és visszaszerzésében, ezért is külön nyújtó hatású edzések mellett ajánlott a jóga vagy pilátesz edzésforma, hiszen ezek a stabilitás 
mellett megfelelő és helyes nyújtási ingert adnak az izomzatnak. A nagy intenzitású mozgástevékenység végén elengedhetetlen a lazítás, az izmokban felgyülemlett feszültség levezetése, amelyre néhány perces laza futás, óvatos, könnyü statikus nyújtás ugyancsak alkalmas lehet, hiszen ezáltal fenntartjuk az izmok keringését, segítjük a salakanyagok kiürülését, amely csökkenti az izomláz kifejlődését, és elindítja a regenerációt (Pavlik, 2019).

A két, korábban bemutatott szemlélet alapján választ kaphatunk a „mit” kérdésére, vagyis mely izmokat nyújtsuk. A tónusos izmok berövidülése, valamint az egyes mobilis ízületek kontraktúrája az ülő munkavégzés és egyes sporttevékenységek során is bekövetkezhet. Ezért a boka-, csípőízület, háti gerincszakasz mobilizálására, az adott ízületek környéki izmok statikus nyújtására nagy hangsúlyt kell fektetni. Mindemellett fokozott figyelmet igényel a vádli, a comb feszíto, a csípőhorpasz, comb hajlítók, a mély hátizmok, a nagy mellizom és a felületes hátizmok felső szakaszának nyújtása.

\section{A rekreációs sportte- vékenységekben szem elött tartandó elvek}

\section{Irodalomjegyzék}

Apor, P. - Jákó, P. (2007): A krónikus betegségek kezelése edzéssel. Sportorvosi szemle. 48. 31-38. o.

Bailey, R. - Hillman, C. - Arent, S. - Petitpas, A. (2013): Physical Activity: An Underestimated Investment in Human Capital? Journal of Physical Activity and Health. 10. 289-309. DOI: 10.1123/jpah.10.3.289

Balogh, L. (2015). Bevezetés a sportdiagnosztikába. Campus Kiadó, Debrecen.

Boyle, M. (2016): Funkcionális edzés újratöltve. Jaffa Kiadó, Budapest.

Cabane, C. - Lechner, M. (2014): Physical activity of adults: A survey of correlates, determinants, and effects. ZEW Discussion Papers. 14. 088. 1-49 DOI: 10.2139/ ssrn.2523376

D’Anna - Cristiana, G. - Paloma - Filippo (2015): Dynamic stretching versus static stretching in gymnastic performance, Journal of Human Sport and Exercise. 10. 1. 437446. DOI:10.14198/jhse.2015.10.Proc1.37

Fletcher, I.M - Jones, B. (2005): The effect of different warm-up stretch protocols on 20

\begin{tabular}{|c|c|}
\hline Ízület & \begin{tabular}{|} 
Elsődleges funkció \\
\hline Boka
\end{tabular} \\
\hline Térd & Mobilitás (szagittális sík) \\
\hline Csípő & Stabilitás \\
\hline Ágyéki gerincszakasz & Mobilitás \\
\hline Háti gerincszakasz & Stabilitás \\
\hline Lapocka & Mobilitás \\
\hline $\begin{array}{c}\text { Glenohumerális (lapocka- } \\
\text { felkarcsonti) ízület }\end{array}$ & Stabilitás \\
\hline
\end{tabular}

1. táblázat: Az „ízületről ízületre” elv. (Boyle, 2014) / Joint by joint approach

Érdemes úgy alakítani a mozgásprogramokat, hogy az a testtartás és testalkat szempontjából hasznos legyen.

A következőkben két - az izmok berövidülésével és az ízületek beszúkülésével (kontraktúrájával) kapcsolatos - fontos szemléletet mutatunk be, melyek ismeretében differenciáltabban alkalmazhatóak az előzőekben ismertetett nyújtási technikák.

Elsőként Gray Cook „ízületről ízületre" történő testfelépítését járjuk körül.

Az elmélet lényege, hogy az emberi testben minden ízületnek vagy ízületsornak van egy fó funkciója (mobilitás vagy stabilitás) és ki van téve egy előre látható „múködési zavarnak", emiatt minden ízületnek eltérő edzésigénye van (1 1 táblázat).

Ha egy ízület nem megfelelően tud múködni, például a bokaízület kontraktúrássá válik (elveszti mobilitását), akkor a térdízületnek kell mobilisnek lennie, ami a térd stabil mivoltából fakadóan térdsérüléshez vezethet.

A rekreációs fizikai aktivitás során rövid és hosszú távon egyaránt érdemes figyelni az ízületek állapotát és állandó nyújtásokat alkalmazni a mobilis ízületek funkciójának megôrzése érdekében.

Ezáltal elkerülhetőbbek az akut és krónikus sérülések, fájdalmak. meter sprint performance in trained rugby union players. Journal of Strength and Conditioning Research. 18. 4. 885-888.

Fritz, P. (szerk.) (2018): Alapfogalmak és jelentéseik a rekreáció területén. Rekreáció mindenkinek III. Szeged.

Ihász, F. - Liziczai, I. - Raffai, A. (2015): A terheléses EKG prediktiv szerepe a középkorú hobbisportolók körében. Magyar Sporttudományi Szemle 16. 2. 37. o.

Janda, V. (1986): Muskelfunktionsdiagnostik. Berlin. VV Volk und Gesundheit.

Little, L. - Williams, A.G. (2006): Effects of differential stretching protocols during warm-ups on high-speed motor capacities in professional soccer players. Journal of Strength and Conditioning Research. 20. 1. 203-207. DOI:10.1519/R-16944.1

Metzing, M. (2010): Gimnasztika. Budapest.

Müller, A. - Rácz, I. (2011): Aerobik és fitnesz irányzatok. Dialóg Campus Kiadó-Nordex Kft.

Pavlik, G. (2015): A rendszeres fizikai aktivitás szerepe betegségek megelőzésében, az egészség megörzésében. Egészségtudomány. 55. 2.
Pavlik, G. (2019): Élettan-Sportélettan, Medicina Könyvkiadó Zrt,. Budapest.

Radák, Zs. (2016): Edzésélettan. Krea-fitt Kft., Budapest.

Saoulidis, J. - Yiannakos, Ath. - Galazoulas, Ch. - Zaggelidis G. - Armatas, V. Aristotle (2010): Acute Effect of Short Passive and Dynamic Stretching on 20m Sprint Performance in Handball Players. Physical Training.

Somhegyi, A. - Gardi, Zs. - Feszthammer A. - Darabosné, T. I. - Tóthné, S. V. (2003): Tartáskorrekció. Co-Print Kft., Budapest.

Tánczos, Z. (2018): Fitnesz és személyi edzés. Krea-fitt Kft., Budapest.

Váczi, M. (2015): A vázizom működésének neuromechanikai alapjai. Pécs.

Vannai, J. (2019): Gyermeksport. Krea-fitt Kft., Budapest.

Zmijewski P. - Lipinska P. - Czajkowska A. - Mróz A. - Kapuściński P. - Mazurek K. (2020): Acute Effects of a Static vs. a Dynamic Stretching Warm-up on Repeated-Sprint Performance in Female Handball Players. Journal of Human Kinetics volume 72. 161-172. DOI: 10.2478/hukin-2019-0043. 